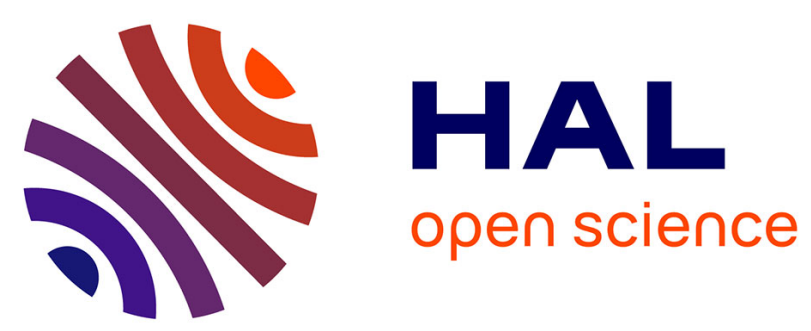

\title{
Disambiguating phrasal verbs
}

Peter Machonis

\section{To cite this version:}

Peter Machonis. Disambiguating phrasal verbs. Lingvisticae Investigationes, 2008, 25th Lexis and Grammar Conference, 31 (2), pp.200-212. 10.1075/li.31.2.06mac . hal-01369868

\section{HAL Id: hal-01369868 https://hal.science/hal-01369868}

Submitted on 21 Sep 2016

HAL is a multi-disciplinary open access archive for the deposit and dissemination of scientific research documents, whether they are published or not. The documents may come from teaching and research institutions in France or abroad, or from public or private research centers.
L'archive ouverte pluridisciplinaire HAL, est destinée au dépôt et à la diffusion de documents scientifiques de niveau recherche, publiés ou non, émanant des établissements d'enseignement et de recherche français ou étrangers, des laboratoires publics ou privés. 


\title{
Disambiguating phrasal verbs
}

\author{
Peter A. Machonis \\ Florida International University
}

\section{Introduction}

In Natural Language Processing (NLP), there has been much recent interest concerning phrasal verbs and other multiword expressions (Dehé 2002, Guenthner \& Blanco 2004, Sag et al. 2002). Transitive phrasal verbs for the most part exhibit a continuous and discontinuous form:

\section{(1) We cleared up the problem $\Leftrightarrow$ We cleared the problem up}

Furthermore, in the case of a pronominal direct object, only the discontinuous form is grammatical:

\section{(2) We cleared it up $\Leftrightarrow *$ We cleared up it}

Linguists debate where and how to store these expressions in the lexicon, how to electronically identify discontinuous strings in a corpus, and if the underlying form should theoretically be considered the continuous or discontinuous one. However, one very practical problem for NLP remains: disambiguating lexically identical, but semantically different expressions. The difference in meaning is by and large determined by the nature of the object rather than the subject, as the following examples show:
a. The mother picked up the children
[= stop for $]$
b. The police picked up the drug dealer
$[=$ arrest $]$
c. The student picked up a new language
[= acquire/learn]
d. The gentleman picked up the young lady
[= make contact with $]$
e. The editor picked up the errors
[= notice]
f. Anne picked up dinner
[= buy $]$

This study enlarges the systematic description of the most productive particle used in English phrasal verb constructions: up. The initial database, composed of 
300 transitive occurrences of up, collected from The American Heritage Dictionary and Spears 1996, was expanded to over 700 occurrences with the help of Fraser (1976) and two other phrasal verbs dictionaries: The Longman Phrasal Verbs Dictionary (2000) and The Cambridge International Dictionary of Phrasal Verbs (1997).

In this expansion, we also included some support verbs (e.g., throw, put) involving particle movement, such as:

(4) a. The engineers quickly (threw up + put up) the building $\Leftrightarrow$ The engineers quickly (threw + put) the building up [= assemble] b. The building is finally up [= finished being built or assembled]

Since they may also be continuous or discontinuous, we integrated adverbials, or spatial particles (Jackendoff 2002), in our database, as well:

(5) Max (kicked + threw + tossed) up the ball $\Leftrightarrow$ Max (kicked + threw + tossed) the ball up

(6) Mary flipped up the switch $\Leftrightarrow$ Mary flipped the switch up

Finally, to highlight all possible ambiguity, we included what are often called prepositional verbs. These are similar to phrasal verbs, but they do not involve movement of the particle or preposition up, such as:

(7) a. Women make up [= comprise] $90 \%$ of the applicants, while men make up the rest

b. *Women make $90 \%$ of the applicants up, while men make the rest up

(8) a. The Florida Marlins rang up [= accomplish] 6 runs in the last inning

b. *The Florida Marlins rang 6 runs up in the last inning

We also incorporated some reduced structures as well, but obvious prepositional phrases, such as:

\section{(9) The hurricane chugged up the peninsula}

were not included in our data.

\section{Compositionality and neutrality}

The particle up appears to be often used as an intensifier or as an aspect marker, which changes the activity into one of accomplishment, and can be deleted in almost $40 \%$ of the cases examined. We refer to these as compositional ${ }^{1}$ phrasal $^{2}$ verbs, since in most cases they are clearly not frozen expressions, but rather regular verbs that can be modified with a particle: 
They drank up the soda $\Leftrightarrow$ They drank the soda up $\Leftrightarrow$ They drank the soda

Max heated up the water $\Leftrightarrow$ Max heated the water up $\Leftrightarrow$ Max heated the water

Furthermore, 25\% of the expressions listed exhibit neutrality (Boons, Guillet, $\&$ Leclère 1976) or the causative alternation (Levin 1993) such as:

(12) We cleared up the problem $\Leftrightarrow$ The problem cleared up

(13) Laura burned up the house $\Leftrightarrow$ The house burned up

In many cases, typically neutral verbs (e.g., burn, break, etc.), remain neutral when followed by the particle up:

$$
\begin{aligned}
& \text { The decision burned up Max [= make angry] } \Leftrightarrow \text { Max burned up } \\
& \text { The comic broke up the audience [= cause to laugh] } \\
& \Leftrightarrow \text { The audience broke up }
\end{aligned}
$$

This is not always the case, though:

$$
\begin{aligned}
& \text { The driver burned up the track [= travel at high speed] } \\
& \Leftrightarrow \text { *The track burned up }
\end{aligned}
$$

An unanticipated observation, however, was that a large number of transitive verbs that are typically not neutral, took on the property of neutral verbs when followed by up. For example, transitive verbs such as hike, line, and power are not generally classified as neutral verbs, but with the added particle they can become neutral:

(17) a. Max hiked the trail $\Leftrightarrow *$ The trail hiked

b. The company hiked up gas prices [= increase] $\Leftrightarrow$ Gas prices hiked up

(18) a. FPL powered the building $\Leftrightarrow *$ The building powered

b. Max powered up the engine [= start] $\Leftrightarrow$ The engine powered up

Conversely, in a few cases, some typically neutral verbs did not accept the intransitive when the particle was added:

$$
\begin{aligned}
& \text { The cook boiled }(E+\text { up) the water } \\
& \Leftrightarrow \text { The water was boiling }\left(E+*^{*}\right. \text { up) } \\
& \text { The garlic smells }\left({ }^{*} E+\right.\text { up) the kitchen } \\
& \Leftrightarrow \text { The kitchen smells }\left(E+*^{*} \text { up }\right)
\end{aligned}
$$

These exceptions confirm the necessity of listing each expression in lexicongrammar tables. 


\section{Lexicon-Grammar tables}

Originally, we had divided the data into five separate tables, depending on whether the particle was optional and if the expression exhibited neutrality:

$\begin{array}{llll}\text { Transitive verb }+ \text { up } & 356 \text { cases } & 49.5 \% & \text { bring up } \mathrm{N}_{1} \\ \text { Neutral verb }+ \text { up } & 92 \text { cases } & 12.5 \% & \text { clear up } \mathrm{N}_{1} \\ \text { Transitive verb + optional up } & 176 \text { cases } & 24.5 \% & \text { drink }(\mathrm{E}+\mathrm{up}) \mathrm{N}_{1} \\ \text { Neutral verb }+ \text { optional up } & 89 \text { cases } & 12.5 \% & \text { burn }\left(\mathrm{E}+\text { up) } \mathrm{N}_{1}\right. \\ \text { Other: Neutral in } \mathrm{N}_{1} \mathrm{~V} \text { only } & 8 \text { cases } & 1 \% & \text { boil }\left(\mathrm{E}+\text { up) } \mathrm{N}_{1} \text {, smell up } \mathrm{N}_{1}\right.\end{array}$

For this study, however, we combined all the tables into one large database in order to consider the problem of ambiguity involving homonyms from different tables. As can be seen in the following sample tables, extracted from the general database, these various syntactic possibilities are indicated via transformations along with the nature of the subject and object. The transformations categorized include particle deletion, the causative (or neutral) alternation with particle, and the causative (or neutral) alternation without particle. Finally, semantic information in the form of a synonym is included.

In the final database of 721 up expressions, 64\% are ambiguous. Of these ambiguous expressions, over $60 \%$ involve just two or three homonyms, such as crack up the audience [= make laugh] vs. crack up the car [= damage], whereas about $20 \%$ comprise four or five homonyms, such as bring up or burn up (cf. Tables 6 \& 7). But some include nine or ten cases, such as throw up (cf. Table 8), while the expression pick up has at least fourteen distinct meanings, as can be seen in Table 1, where a French translation is also provided to underscore the difficulties this presents to NLP.

Since phrasal verbs, like regular one-word verbs, can be ambiguous in the lexicon, explicit selectional restrictions and other semantic features are needed in our lexicon-grammar in order to distinguish the various uses of the same expression in NLP. In some cases, the selectional restrictions of the direct object, which were limited to the features of [+ human] and [- human] in this classification, seemed to suffice. But, since differences in meaning are most often determined by the nature of the object, we have recently begun to expand our categorization to describe the object more fully. 


\begin{tabular}{|c|c|c|c|c|c|c|c|c|c|c|c|}
\hline 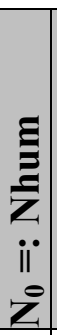 & 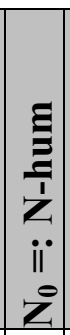 & $\frac{0}{2}$ & 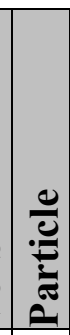 & Example of $\mathrm{N}_{1}$ & \begin{tabular}{|c}
$\mathbf{E}$ \\
$\mathbf{Z}$ \\
$\mathbf{Z}$ \\
ii \\
$\bar{Z}$ \\
\end{tabular} & $\begin{array}{c}\mathrm{E} \\
\mathbf{z} \\
\mathbf{Z} \\
\mathbf{Z} \\
\mathrm{ii} \\
\mathbf{z}\end{array}$ & 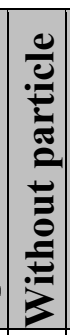 & $\begin{array}{l}2 \\
\bar{z} \\
2 \\
z \\
z \\
z\end{array}$ & $\begin{array}{l}z \\
\bar{z}\end{array}$ & Synonym & $\begin{array}{c}\text { French } \\
\text { Translation } \\
\end{array}$ \\
\hline+ & - & pick & up & a new language & - & + & - & - & - & acquire / learn & apprendre \\
\hline+ & - & pick & up & the drug dealer & + & - & - & - & - & $\begin{array}{c}\text { arrest / take into } \\
\text { custody }\end{array}$ & $\begin{array}{c}\text { arrêter, placer } \\
\text { en détention } \\
\text { préventive }\end{array}$ \\
\hline+ & - & pick & up & dinner & - & + & - & - & - & buy / acquire & acheter \\
\hline+ & + & pick & up & the debris & + & + & - & - & - & $\begin{array}{c}\text { collect / lift / } \\
\text { gather }\end{array}$ & $\begin{array}{c}\text { ramasser, } \\
\text { soulever }\end{array}$ \\
\hline+ & + & pick & up & the phone & - & + & - & - & - & $\begin{array}{c}\text { answer phone / } \\
\text { get messages }\end{array}$ & décrocher \\
\hline+ & - & pick & up & the young lady & + & - & - & - & - & $\begin{array}{c}\text { make contact } \\
\text { with (sexual } \\
\text { intentions) }\end{array}$ & draguer \\
\hline+ & + & pick & up & the error & - & + & - & - & - & notice & relever \\
\hline+ & + & pick & up & the children & + & + & - & - & - & $\begin{array}{c}\text { stop for } \\
\text { (passenger or } \\
\text { item) / call for }\end{array}$ & passer prendre \\
\hline+ & + & pick & up & Max & + & - & - & - & - & invigorate & $\begin{array}{l}\text { remonter, } \\
\text { améliorer }\end{array}$ \\
\hline+ & - & pick & up & the bedroom & - & + & - & - & - & clean & nettoyer \\
\hline+ & - & pick & up & the discussion & - & + & - & - & - & continue & reprendre \\
\hline+ & + & pick & up & the award & - & + & - & - & - & win / earn & gagner \\
\hline+ & + & pick & up & the radio station & - & + & - & - & - & obtain signal & capter \\
\hline+ & - & pick & up & a cold & - & + & - & - & - & $\begin{array}{c}\text { get an infectious } \\
\text { disease }\end{array}$ & attraper \\
\hline
\end{tabular}

Table 1. Ambigutity involving the phrasal verb pick up 


\section{Semantic distinctions: Hyperclasses, semantic classes, domains}

Gaston Gross (1994, 2004) and other researchers at LLI (e.g., Le Pesant \& Mathieu-Colas 1998) have previously introduced semantic factors or "classes d'objets" into linguistic data. Basically, arguments are classified according to semantic classes, which in turn correspond to semantic classes that predicates may take. Thus the meaning of a polysemous predicate can be automatically recognized in a text, if the arguments are also catalogued in this manner. But classifying each phrasal verb as accepting certain general hyperclasses or "traits" and more refined semantic classes or "classes d'objets" was so overwhelming for this initial study in ambiguity that we decided to see if a limited number of features associated with acceptable objects would suffice to mitigate the ambiguity with the phrasal verbs in question. We started with the eight hyperclasses from Gross 1994: human, animal, plant, inanimate (concrete), inanimate (abstract), location, time, and event. We then developed basic semantic classes as we sifted through our data of ambiguous phrasal verbs, such as beverage, body part, business, clothing, food, fuel, hobby/skill, information, machine, money, musical instrument, vehicle, and so forth, along with other semantic information, such as energy, false, hostile, list, undesirable, etc.

Let us start with some of the straightforward cases, i.e., those involving just two distinct meanings. Objects identified as only accepting [+ human] complements were simply marked as human under hyperclass. Likewise those only taking [- human] complements were merely labeled as concrete. In fact, some ambiguous pairs of phrasal verbs can be distinguished in this straightforward manner, as can be seen in Table 2 . But this only happens in $16 \%$ of the cases examined: i.e., only 13 out of 83 pairs can be disambiguated in this fashion.

Next we looked at cases involving two homophonous phrasal verbs both requiring direct objects that are [- human]. Here we tried to hone in on the various groups of possible lexical items associated with each meaning. In some cases, the hyperclasses were sufficient to disambiguate; in others, semantic classes were necessary, as can be seen in Table 3 . It is obvious that if we look at this on a continuum, the more free the expression, the more vague the semantic information can be, whereas, the more frozen the expression, the easier it is to define a limited semantic class of possible objects.

After that, we tried to distinguish cases where one expression accepts only [- human] complements and the other takes both [+ or - human], such as tune up, which can mean both "adjust engine" as well as "adjust musical pitch", as in Table 4. Again, more specific semantic features such as body part, drug, coin, and vehicle, along with the hyperclass helped to alleviate the ambiguity between 
the two separate connotations. In some cases, however, only pragmatics, a longer chunk of text, or the identification of an elision can resolve all ambiguity:

(21) a. Max lifted up the patient

[= raise the patient (literally, e.g., out of bed)]

b. Max's good humor lifted up the patient

[= increase (emotionally) the patient's spirits]

(22)

a. Ann decided to look up Max

[= find Max's name in the telephone book]

b. Ann decided to look up Max [= visit Max]

Subsequently, we examined cases of ambiguity involving more than two distinct meanings. In some cases, hyperclasses in themselves were sufficient to disambiguate, as in Table 5. Even though the various meanings of brighten up are very closely connected, and perhaps might not be considered homophonous by all, we do observe divergent syntactic behavior, either in terms of transformations or selectional restrictions between the various shades of meaning.

\begin{tabular}{|c|c|c|c|c|c|c|c|c|c|c|c|}
\hline $\begin{array}{c}\mathbf{\Xi} \\
\mathbf{\Xi} \\
\overline{\mathbf{Z}} \\
\mathrm{iI} \\
\mathbf{0}\end{array}$ & $\begin{array}{c}\mathbf{E} \\
\mathbf{Z} \\
\mathbf{Z} \\
\mathbf{Z} \\
\ddot{i} \\
\dot{Z} \\
\mathbf{Z}\end{array}$ & Verb & שֶ & $\begin{array}{c}\text { Example of } \\
N_{1}\end{array}$ & $\mid \begin{array}{c}\equiv \\
\mathbf{z} \\
\mathbf{z} \\
\text { ii } \\
\bar{Z} \\
\end{array}$ & $\begin{array}{c}\text { E } \\
\mathbf{Z} \\
\overline{\mathbf{T}} \\
\mathbf{Z} \\
\mathrm{ii} \\
\overline{\mathrm{Z}}\end{array}$ & 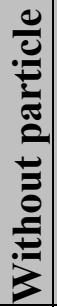 & $\begin{array}{l}\overline{2} \\
\bar{z} \\
\bar{z} \\
z \\
z\end{array}$ & $\vec{z}$ & Synonym & Hyperclass \\
\hline+ & + & bundle & up & the magazines & - & + & + & - & - & bundle & concrete \\
\hline+ & - & bundle & up & the child & + & - & + & + & - & dress warmly & human \\
\hline+ & + & bust & up & the audience & + & - & - & + & - & make laugh & human \\
\hline+ & + & bust & up & the machine & - & + & + & - & - & break & concrete \\
\hline+ & + & choke & up & the pipes & - & + & - & - & - & clog & concrete \\
\hline+ & + & choke & up & the audience & + & - & - & + & - & cause to feel sad & human \\
\hline+ & + & crack & up & the audience & + & - & - & + & - & make laugh & human \\
\hline+ & + & crack & up & the car & - & + & - & - & - & damage & concrete \\
\hline+ & - & get & up & a committee & - & + & - & - & - & organize / form & concrete \\
\hline+ & + & get & up & Max & + & - & - & + & - & awaken & human \\
\hline
\end{tabular}

Table 2. Disambiguation through human or concrete direct objects 


\begin{tabular}{|c|l|l|l|l|l|l|l|l|l|}
\hline & & & & & & & \\
\end{tabular}

Table 3. Disambiguation through semantic classes when object is [- human]

For other cases of ambiguity involving more than two meanings, a larger context is needed to fully distinguish these expressions. In these cases, we followed Le Pesant \& Mathieu-Colas 1998 and introduced domains, along with hyperclasses and semantic classes, as seen in Table 6. 


\begin{tabular}{|c|c|c|c|c|c|c|c|c|c|c|c|c|}
\hline 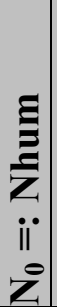 & 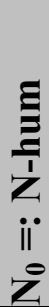 & Verb & $\mid$ & $\begin{array}{c}\text { Example } \\
\text { of } N_{1}\end{array}$ & 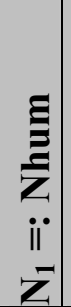 & 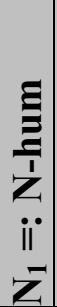 & 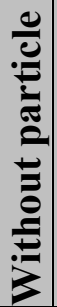 & 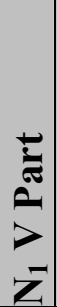 & $\bar{z}$ & Synonym & $\begin{array}{c}\text { Hyper- } \\
\text { class }\end{array}$ & $\begin{array}{c}\text { Semantic } \\
\text { Class }\end{array}$ \\
\hline+ & + & jack & up & the car & + & + & - & - & - & raise & $\begin{array}{l}\text { human / } \\
\text { concrete }\end{array}$ & $\begin{array}{c}\text { vehicle / } \\
\text { heavy } \\
\text { object } \\
\end{array}$ \\
\hline+ & + & jack & up & the prices & - & + & + & + & - & increase & concrete & $\begin{array}{c}\text { money / } \\
\text { rate }\end{array}$ \\
\hline+ & - & look & up & $\begin{array}{l}\text { the phone } \\
\text { number }\end{array}$ & + & + & - & - & - & $\begin{array}{l}\text { find in a } \\
\text { book, list, } \\
\text { index, etc. }\end{array}$ & $\begin{array}{l}\text { human / } \\
\text { concrete }\end{array}$ & $\begin{array}{c}\text { information } \\
\text { / list }\end{array}$ \\
\hline+ & - & look & up & Max & + & - & - & - & - & visit & human & \\
\hline+ & + & loosen & up & the wire & - & + & + & + & + & $\begin{array}{c}\text { make less } \\
\text { tight }\end{array}$ & concrete & \\
\hline+ & + & loosen & up & $\begin{array}{l}\text { my } \\
\text { shoulders }\end{array}$ & + & + & + & + & - & relax & $\begin{array}{l}\text { human / } \\
\text { concrete }\end{array}$ & $\begin{array}{c}\text { body part / } \\
\text { human }\end{array}$ \\
\hline+ & + & shoot & up & the village & + & + & - & - & - & $\begin{array}{l}\text { damage by } \\
\text { gunfire }\end{array}$ & $\begin{array}{l}\text { human / } \\
\text { concrete }\end{array}$ & $\begin{array}{l}\text { human / } \\
\text { location }\end{array}$ \\
\hline+ & - & shoot & up & heroin & - & + & + & - & - & inject (drug) & concrete & drug \\
\hline+ & + & tighten & up & $\begin{array}{l}\text { the } \\
\text { muscles }\end{array}$ & + & + & - & + & + & make tense & $\begin{array}{l}\text { human / } \\
\text { concrete }\end{array}$ & body part \\
\hline+ & + & tighten & up & the wire & - & + & + & + & + & tighten & concrete & \\
\hline+ & + & toss & up & the blanket & + & + & - & - & - & $\begin{array}{l}\text { throw } \\
\text { upwards }\end{array}$ & concrete & \\
\hline+ & - & toss & up & the penny & - & + & + & - & - & $\begin{array}{c}\text { throw in air } \\
\text { to determine } \\
\text { outcome }\end{array}$ & concrete & coin \\
\hline+ & - & tune & up & the car & - & + & + & - & - & adjust engine & concrete & vehicle \\
\hline+ & - & tune & up & $\begin{array}{l}\text { the brass } \\
\text { section }\end{array}$ & + & + & + & + & + & adjust pitch & $\begin{array}{l}\text { human / } \\
\text { concrete }\end{array}$ & $\begin{array}{l}\text { musical } \\
\text { instrument } \\
/ \text { musician }\end{array}$ \\
\hline
\end{tabular}

Table 4. Disambiguation when object can be either [+ human] or [- human] 


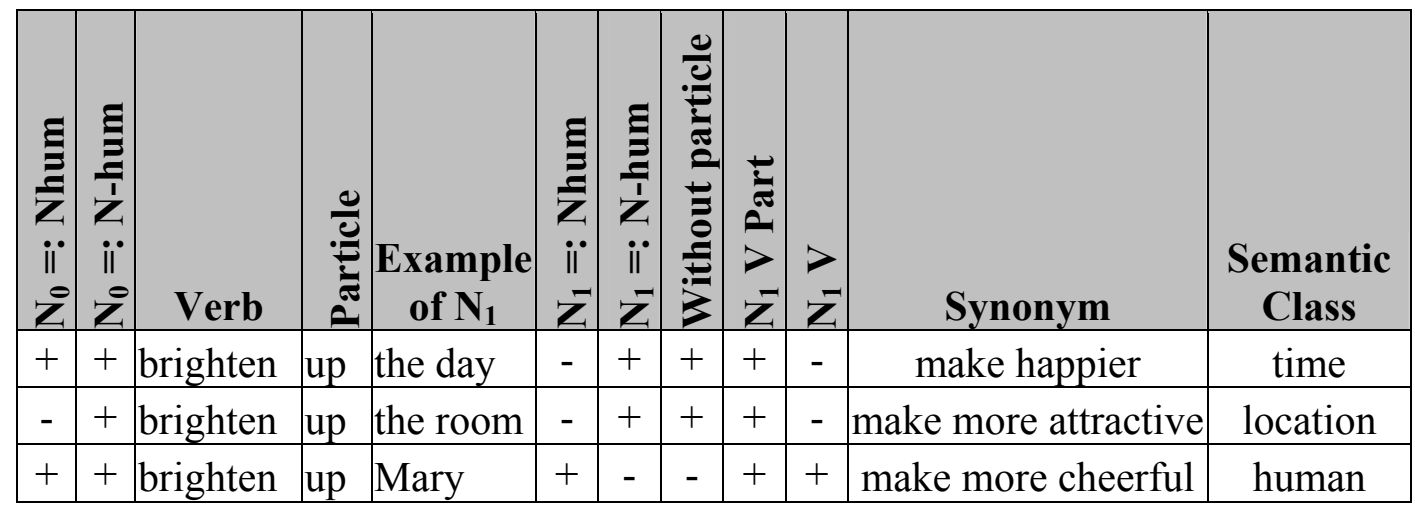

Table 5. Disambiguation of brighten up

\begin{tabular}{|l|l|l|l|l|l|l|l|l|l|l|}
\hline & & & & & & & \\
\\
+
\end{tabular}

Table 6. Disambiguation of bring up

Here, in Table 6, the phrasal verb bring up translates into French as "accuser," "soulever," "élever," "vomir," or "apporter," depending on the domain or context. Although it remains to be seen how we can precisely identify these domains by way of NLP programming, that information can nevertheless help disambiguate a sentence such as: 
(23) a. The parents brought up the baby [= mention in a conversation]

b. The parents brought up the baby [= raise/ educate, as a child]

c. The parents brought up the baby [= carry up to a specific location]

\section{Semi-frozen vs. free expressions}

There are many cases where the verb-particle combination along with the complement is indisputably idiomatic or frozen since only one complement is possible, as in live it up "party extravagantly" or where only a couple of complements are possible, as in pick up (speed + steam) "go faster". However, some phrasal verbs exist in very limited paradigms and might be construed as semi-idioms, whereas others accept a variety of complements and can be considered freer. For example, in Table 7, the first three cases have very limited domains - burn up the (raceway + speedway + track $)$, burn up $($ energy + fat + calories), and burn up (fuel + gas + money) - while the last two meanings "destroy by fire" and "make angry" are less restricted as to possible complements, are able to be composed without the particle, and can be considered compositional.

\begin{tabular}{|c|c|c|c|c|c|c|c|c|c|c|c|c|c|}
\hline 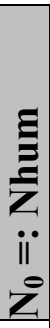 & 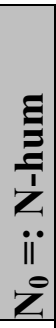 & Verb & 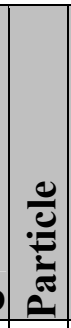 & 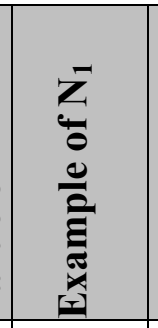 & $\begin{array}{c}\text { E } \\
\text { 三 } \\
\overline{\mathbf{Z}} \\
\mathrm{ii} \\
\mathbf{Z}\end{array}$ & 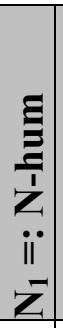 & 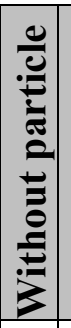 & 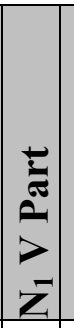 & $\vec{z}$ & Synonym & $\begin{array}{c}\text { Hyper- } \\
\text { class }\end{array}$ & $\begin{array}{c}\text { Semantic } \\
\text { Class }\end{array}$ & Domain \\
\hline+ & + & burn & up & $\begin{array}{l}\text { the } \\
\text { track }\end{array}$ & - & + & - & - & - & $\begin{array}{c}\text { travel at } \\
\text { high speed }\end{array}$ & con & roadway & racing \\
\hline+ & + & burn & up & money & - & + & - & - & - & $\begin{array}{l}\text { use too } \\
\text { much }\end{array}$ & concrete & $\begin{array}{c}\text { money / } \\
\text { fuel }\end{array}$ & spending \\
\hline+ & - & burn & up & calories & - & + & + & - & - & consume & concrete & energy & exercise \\
\hline+ & + & burn & up & \begin{tabular}{|l} 
the \\
barn
\end{tabular} & + & + & + & + & + & \begin{tabular}{|c|}
$\begin{array}{c}\text { destroy by } \\
\text { fire }\end{array}$ \\
\end{tabular} & $\begin{array}{l}\text { human / } \\
\text { concrete }\end{array}$ & location & fire \\
\hline+ & + & burn & up & Max & + & - & + & + & - & $\begin{array}{l}\text { make } \\
\text { angry }\end{array}$ & human & human & $\begin{array}{l}\text { emotion- } \\
\text { al state }\end{array}$ \\
\hline
\end{tabular}

Table 7. Disambiguation of burn up 


\section{Peter A. Machonis}

Finally, in Table 8, while the first case of "throw upwards" can be construed as compositional, accepting many possible complements and difficult to distinguish from some of the more idiomatic senses, the other eight cases can be clearly distinguished by semantic classes.

\begin{tabular}{|c|c|c|c|c|c|c|c|c|c|c|c|c|}
\hline 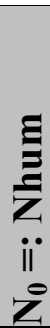 & 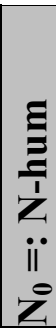 & Verb & 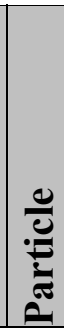 & $\begin{array}{c}\text { Example } \\
\text { of } N_{1}\end{array}$ & $\begin{array}{c}\mathbf{E} \\
\mathbf{Z} \\
\overline{\mathbf{Z}} \\
\mathrm{ii} \\
\overline{\mathbf{Z}}\end{array}$ & $\begin{array}{c}\text { E } \\
\bar{Z} \\
\bar{Z} \\
\bar{Z} \\
\text { ii } \\
\bar{Z}\end{array}$ & $\begin{array}{l}0 \\
0 \\
0 \\
0\end{array}$ & $\begin{array}{l}\bar{Z} \\
\bar{z} \\
\bar{z} \\
\bar{z}\end{array}$ & $\bar{z}$ & Synonym & $\begin{array}{c}\text { Hyper- } \\
\text { class }\end{array}$ & $\begin{array}{c}\text { Semantic } \\
\text { Class }\end{array}$ \\
\hline+ & - & throw & up & the ball & + & + & + & - & - & $\begin{array}{c}\text { throw } \\
\text { upwards }\end{array}$ & $\begin{array}{l}\text { human / } \\
\text { concrete }\end{array}$ & \\
\hline+ & - & throw & up & $\begin{array}{l}\text { POSS-0 } \\
\text { hands }\end{array}$ & - & + & - & - & - & $\begin{array}{c}\text { raise } \\
\text { upwards } \\
\text { suddenly }\end{array}$ & concrete & $\begin{array}{c}\text { upper body } \\
\text { part }\end{array}$ \\
\hline+ & + & throw & up & $\begin{array}{l}\text { the } \\
\text { building }\end{array}$ & - & + & - & - & - & erect quickly & $\begin{array}{c}\text { concrete / } \\
\text { location }\end{array}$ & building \\
\hline+ & - & throw & up & dinner & - & + & - & - & - & vomit & concrete & food \\
\hline- & + & throw & up & dust & - & + & - & - & - & cause to rise & concrete & cloud / haze \\
\hline+ & - & throw & up & $\begin{array}{l}\text { the } \\
\text { campaign }\end{array}$ & - & + & - & - & - & abandon & concrete & job/project \\
\hline+ & + & throw & up & the slides & - & + & - & - & - & project & concrete & $\begin{array}{l}\text { recorded } \\
\text { image }\end{array}$ \\
\hline+ & - & throw & up & the past & - & + & - & - & - & $\begin{array}{c}\text { refer } \\
\text { repeatedly to }\end{array}$ & abstract & old \\
\hline+ & + & throw & up & $\begin{array}{l}\text { some } \\
\text { ideas }\end{array}$ & - & + & - & - & - & produce & abstract & new \\
\hline
\end{tabular}

Table 8. Disambiguation of throw up

\section{Conclusion}

We conclude that subcategorization refinements, such as hyperclasses, semantic classes, and domains help mitigate ambiguity involving English phrasal verbs. 
However, some uncertainty still remains, when the ambiguity involves subject commutation, as the following examples show:

(24) a. The police broke up the crowd

b. The comedian broke up the crowd

25) a. Max took out Mary

b. The hit men took out Mary

(26) a. The student marked up the textbook

b. The bookstore manager marked up the textbook [= raise the price of]

Expanding the selectional restrictions of the subject in the lexicon-grammar will clearly help solve the issue of ambiguity, but better defining context or domains is the only way to fully distinguish diverse meanings of lexically uniform phrasal verbs. Our data nevertheless underscore the importance of a lexicon-grammar approach to English phrasal verbs.

\section{Note}

1. We refer to these as compositional, since the particle can basically be viewed as an intensifier (beat up the kids), an aspect marker (boot up the computer), or an adverbial (drive up prices) that is added to the one-word verb. Some cases where the particle can be deleted, however, do involve idiomatic or non-compositional expressions, such as the following:

$i$. The administrator backed $(u p+E)$ the teacher [= support $]$

ii. The situation was eating $(u p+E)$ Mary $\quad[=$ bother $]$

\section{References}

American Heritage Dictionary of the English Language. Fourth Edition. 2000. Boston: Houghton Mifflin Company.

Boons, Jean-Paul, Alain Guillet, \& Christian Leclère. 1976. La structure des phrases simples en français. Constructions intransitives. Geneva: Droz.

Cambridge International Dictionary of Phrasal Verbs. 1997. Cambridge: Cambridge University Press.

Dehé, Nicole. 2002. ParticleVerbs in English. Syntax, Information Structure and Intonation. Amsterdam/Philadelphia: John Benjamins.

Fraser, Bruce. 1976. The Verb-particle Combination in English. New York: Academic Press.

Gross, Gaston. 1994. Classes d'objets et description des verbes. Langages 115.15-30.

Gross, Gaston. 2004. Classes sémantiques et description des langues. In Lexique, Syntaxe et Lexique-Grammaire (Syntax, Lexis \& Lexicon-Grammar) Papers in honour of Maurice Gross, Christian Leclère, Eric Laporte, Mireille Piot \& Max Silberztein (eds.), Lingvisticae Investigationes Supplementa 24.231-238. 
Guenthner, Franz \& Xavier Blanco. 2004. Multi-lexemic expressions: an overview. In Lexique, Syntaxe et Lexique-Grammaire (Syntax, Lexis \& Lexicon-Grammar) Papers in honour of Maurice Gross, Christian Leclère, Eric Laporte, Mireille Piot \& Max Silberztein (eds.), Lingvisticae Investigationes Supplementa 24.239-252.

Jackendoff, Ray. 2002. English Particle Constructions, the Lexicon, and the Autonomy of Syntax. In Verb-particle Explorations, Nicole Dehe, Ray Jackendoff, Andrew McIntyre \& Silke Urban (eds.), 67-94, New York: Mouton de Gruyter.

Le Pesant, Denis \& Michel Mathieu-Colas. 1998. Introduction aux classes d'objets. Langages 131.6-33.

Levin, Beth. 1993. English Verb Classes and Alternations: A Preliminary Investigation. Chicago: University of Chicago Press.

Longman Phrasal Verbs Dictionary. 2000. Essex: Pearson Education Limited.

Sag, Ivan A., Timothy Baldwin, Francis Bond, Ann Copestake, \& Dan Flickinger. 2002. Multiword Expressions: A Pain in the Neck for NLP. In Proceedings of the Third International Conference on Intelligent Text Processing and Computational Linguistics, 1-15, Mexico City: CICLING.

Spears, Richard A. 1996. Basic Phrasal Verbs. Lincolnwood: NTC Publishing Group.

\section{Summary - Disambiguating phrasal verbs}

Like regular one-word verbs, verb-particle combinations or phrasal verbs can be ambiguous in the lexicon. This study examines ways to disambiguate by adding specific semantic features or "classes d'objets" to the lexicon-grammar, along with characteristic syntactic selectional restrictions. We first enlarged the systematic description of the most productive particle used in English phrasal verb constructions: up. The initial database, composed of 300 transitive and neutral occurrences of phrasal verbs with up was expanded, and in the final database of $721 \mathrm{up}$ expressions, $64 \%$ were shown to be ambiguous. Of these ambiguous expressions, over $60 \%$ involve just two or three homonyms, such as crack up the audience [= make laugh] vs. crack up the car [= damage], while another $20 \%$ comprise four or five homonyms. The rest involve six or more homonyms, with the expression pick up having fourteen distinct meanings. Following Gaston Gross (1994, 2004), Le Pesant \& Mathieu-Colas (1998), and other researchers at LLI, we introduce hyperclasses, semantic classes, and domains to the object description of some of our data. These subcategorization refinements seem to help mitigate ambiguity and underscore the importance of a lexicon-grammar approach, which includes both syntactic and semantic information, to English phrasal verbs.

\section{Author's address:}

Peter A. Machonis

Department of Modern Languages

Florida International University

University Park Campus

Miami, FL 33199, USA

machonis@fiu.edu 